\title{
SONG, PROTEST, THE UNIVERSITY, AND THE NATION: DELHI, 2016
}

\author{
Rosinka Chaudhuri \\ Centre for Studies in Social Sciences, Calcutta
}

\section{Abstract}

In the wake of the suicide of Dalit postgraduate student Rohith Vermula in Hyderahabad, protests swept educational centres all over India. It was JNU, however, that became ground zero for dissent, especially after the arrest of student leader K. Kumar. His release from prison put into motion the resistance to curb division of powers in India, and sparked a national dispute on being an anti-national (read terrorist) Indian subject. Among the tools to make their plea visible, JNU students and faculty alike resorted to common denominators of Indian popular culture like Bollywood soundtracks.

Keywords: Anti-national Indian, Kanhaiya Kumar, JNU student protests, Upkaa, Rohit Vermula.

\section{RESUMEN}

Las protestas por el suicidio del estudiante intocable Rohith Vermula en Hyderahabad se extendieron por muchas universidades indias. De todas ellas, la Universidad Nehru en Delhi se convirtió en el epicentro, sobre todo tras el arresto del líder estudiantil Kanhaiya Kumar. La suspensión de su arresto puso en marcha un movimiento en defensa de la división de poderes en India y desencadenó una controversia en torno a la identidad anti-patriótica (léase terrorista). Entre otros instrumentos para hacer visibles su causa, los estudiantes recurrieron a elementos de la cultura popular, como las canciones de Bollywood.

Palabras Clave: Anti-patriotismo, JNU, Kanhaiya Kumar, Protestas estudiantiles, Rohit Vermula, Upkaa. 
If you look up the name Kanhaiya Kumar on the internet, Wikipedia will supply you with a long entry, with sections titled 'Early Life and Political Career' ['early life'?], '2016 Sedition Controversy', etc. on this young Ph.D. student who is now arguably the most famous student leader post-Independence India has ever produced - I doubt the entry existed prior to 2016. "Protests to continue at Indian university after student leader's arrest" was the headline of a Guardian article on the $15^{\text {th }}$ of February 2016, as it went on to report: 'Thousands rally across India as students at Jawaharlal Nehru University (JNU) strike over Kanhaiya Kumar's arrest on sedition charge.' Kanhaiya Kumar's arrest soon snowballed into a major political controversy and has drawn sharp reactions from opposition parties, teachers, students and academics. Students at JNU went on strike over Kumar's arrest, effectively paralysing the University. His parents stated that their son was being victimized for his opposition to rightwing Hindutva politics; a charge that took visual form on TV screens across the country after Kumar was attacked by a group of lawyers led by a BJP (Bhatatiya Janata Party) parliamentarian at the Delhi court to which he had been brought for his hearing on $15^{\text {th }}$ February 2016. On $2^{\text {nd }}$ March, Kumar was granted interim bail by the Delhi High Court, conditional on a 10,000 rupee bail bond and an undertaking that he would not "participate in any anti-national activity."

The 23-page judgment of the Delhi High Court Order began with Justice Pratibha Rani invoking a popular and undoubtedly cheesy patriotic song from the 1967 Hindi film Upkar, to say, in ungrammatical English:

This patriotic song from Upkaar by lyricist Indeevar symbolizes individual characteristics representing by different colours and love for motherland. Spring season is a time when nature becomes green and flower blooms in all colours. This spring, why the colour of peace is eluding the prestigious Jawaharlal Nehru University (JNU) situated in the heart of Delhi, needs to be answered by its students, faculty members and those managing the affairs of this national university. (High Court of Delhi 2016)

Grammar has never been essential to the use of English in India, and indeed today it may be deemed politically incorrect to demand it, even of a judge. So rather than that, it was the manner in which the nation had been figured in terms of a film song that puzzled the few who were interested in following the words of the judgement. Songs and singing, either when invoked by the judge or when sung in protest by the students later, came to inform the notion of the nation-state in a curious way in the first six months of 2016. Definitions of nationalism had already created turmoil in the national sphere preceding this, as a swathe of intellectuals, writers and activists had returned awards and prizes to protest 'intolerance' and came to be vilified as 'anti-national' by the governing dispensation.

1 The Supreme Court's latest order on the issue of sedition should be noted in a caveat: the court decided that sedition charges could not just be levelled against anyone critical of the nation. 
The film song the judge mentioned had compared the country to a garden of peace made by the Buddha and Nanak on which bloomed the flowers Gandhi, Subhash, Tagore and Tilak (Ye baag hain Gautam Nanak ka / Khilte hain aman ke phool yahaan / Gandhi, Subhash, Tagore, Tilak / Aise hain chaman ke phool yahaan). The famous refrain spoke of 'the soil of my country that spews gold, spews diamonds and pearls, the soil of my country. Mere desh ki dharti'. After being released on bail, Kumar went on to make a speech and conclude it by singing a rather different song, which came to be known then as the azadi song. This then went viral on the internet, producing a rap version by someone called Dub Sharma, described as a Chandigarh-based composer and producer, which is advertised on the net with the words: 'This Kanhaiya dub step will make every anti-national proud'. Meanwhile another version was composed and sung by Pushpavathy at Trichur, Kerala, The song was first presented at the "Manushya Sangamam" held at Thrissur and was well received, prompting her to record it. Kanhaiya himself has sung the song at many venues, most recently of all in Calcutta at the Mahajati Sadan on September $8^{\text {th }}$, accompanied this time with the beat of a traditional 'dafli' he brought with him, which resulted, according to news reports, in the entire hall standing up to sing the song with him.

At the time the judgement was delivered, the ticker tape on NDTV $24 \times 7$ ran: 'Kanhaiya gets bail', 'Judge speaks of infection, antibiotics and Bollyood'. Shivam $\mathrm{Vij}$, in an article titled 'Kanhaiya's Bail Judgement Begins With "Mere Desh Ki Dharti”', commented in the Huffington Post on $2^{\text {nd }}$ March: 'Metaphors abound in the Delhi High Court judgement that gave bail to JNU students' union president Kanhaiya Kumar - metaphors that seek to emphasise the value of nationalism" (Vij 2016). More metaphors and more nationalism followed the invocation of the song in the judgement, which also saw the use of anti-national slogans in JNU as a bodily infection. "The thoughts reflected in the slogans raised by some of the students of JNU who organized and participated in that programme cannot be claimed to be protected as fundamental right to freedom of speech and expression. I consider this as a kind of infection from which such students are suffering which needs to be controlled /cured before it becomes an epidemic," it said. "Whenever some infection is spread in a limb, effort is made to cure the same by giving antibiotics orally and if that does not work, by following a second line of treatment. Sometimes it may require surgical intervention also. However, if the infection results in infecting the limb to the extent that it becomes gangrene, amputation is the only treatment," it adds. Concluding the judgement, Justice Rani hoped that Kanhaiya Kumar had had time in jail to introspect on the events that took place in JNU on $9^{\text {th }}$ February. Therefore, "to enable him to remain in the mainstream, at present I am inclined to provide conservative method of treatment," she said, staying with the medical metaphor while granting him bail. 
Time to introspect he had, indeed, had a lot of it in jail, and upon his release on 3 March 2016, Kanhaiya Kumar gave a speech to a huge crowd in an open air amphitheatre in the JNU campus during which he said, most famously, that he was seeking not freedom from India but freedom within India. A journalist in the Indian Express a couple of days later called it 'pure protest-poetry'. 'One doesn't have to share his politics to find pleasure in his language', it went on to say, adding:

I certainly don't want "freedom from capitalism" - in fact, I want much more of it; and yet I found his revolutionary fervour endearing. Here is a young man with a serious rhetorical gift, and a mastery over the Hindi language that is a joy... This is Hindi as it should be declaimed - Hindi as a political rasmalai. One needs to hear the speech, not read it, to appreciate fully the theatre of Kanhaiya's delivery; his sawaal-jawaab with the avid and idealistic crowd; the pregnant pauses, so essential in feats of rhetoric; the cutting humour of the occasion; and the verbal up-yours he delivered to those who would jail him for his views. All the while, another young man waved the Indian flag behind him. This was not sedition. This was the heaven of college life. (Varadarajan 2016).

The point of quoting this particular report, of course, is to underline how even those desiring 'much more' capitalism responded to a young man most avowedly from the Left; I will also take up the category of the 'pure', used here before 'protest poetry', later in the paper. Yet this was certainly not the heaven of college life as that is ordinarily understood; it was undoubtedly an exceptional moment in the political experience of Indians born post-Independence. The speech, delivered close to midnight on a cool March night in Delhi, was more than an hour long, yet for those of us who witnessed it live on our TV screens as it was being broadcast by almost every news channel in India, it was absolutely mesmerising. But before we go to the speech, we need to revisit the context.

\section{WHO IS AN 'ANTI NATIONAL' AND WHO SAYS SO?}

If you typed 'anti-national' into Google Maps in March 2016, you were taken straightaway to the site of the JNU Campus in Delhi; Google blamed it on a bug and said it would try and fix the problem. Writing in The Hindu on $17^{\text {th }}$ February after the arrests of the JNU students, respected columnist for The Hindu, G. Sampath, wrote an article titled 'Who Is An Anti-National?' whose subheading summed up: For both Rohith Vemula and Kanhaiya Kumar, nationalism was about the welfare of the Indian people over that of the Indian state- This political vision made them threats in the eyes of goonda nationalists (my italics). The article began:

Can a bunch of hysterical TV anchors really fool a nation into believing that the brightest students of one of its best universities are "anti-nationals" and their thuggish persecutors, "nationalists"? Can India's famed diversity — of intelligence levels, if nothing else- save it from falling for the tired old game of witch-hunting anti-nationals? Well, the ruling dispensation seems to be betting against it. (Sampath 2016) 
To understand the context of Kanhaiya Kumar's speech, and the issue of anti-nationals and nationalism that dominated the news then, we need to understand the case of Hyderabad University Dalit student, Rohith Vemula, which preceded the disturbances at JNU, as well as the nationalism debate that dominated the news for much of 2015. Let me quote the well-known lines he wrote in his suicide note, reprinted in many newspapers, where he spoke of stardust and disenchantment, blaming nobody, saying:

The value of a man was reduced to his immediate identity and nearest possibility. To a vote. To a number. To a thing. Never was a man treated as a mind. As a glorious thing made up of stardust. In every field, in studies, in streets, in politics, and in dying and living.

[...] I am writing this kind of letter for the first time. My first time of a final letter. Forgive me if I fail to make sense. Maybe I was wrong, all the while, in understanding the world. In understanding love, pain, life, death. There was no urgency. But I always was rushing. Desperate to start a life. All the while, some people, for them, life itself is curse. My birth is my fatal accident. (Vermula 2016)

That fatal accident was to have been born a Dalit, whatever the caste of his father may be, and to have suffered the continuation of a long history of discrimination which continues to this day. 'Justice for Rohith' — the slogan raised in the aftermath of the suicide - was therefore not only justice demanded for Rohith, but for the Dalits as a whole. The issue was brought up at the UN in its 31st session of the Human Rights Council, and of course at universities across India and the world. The crisis at Hyderabad University had been sparked off by the Akhil Bharatiya Vidyarthi Parishad (ABVP) spearheading the persecution of the Ambedkar Students' Association by branding them "anti-national". Its case was taken up by a BJP Member of Parliament, Bandaru Dattatreya, who sent a complaint to the Centre.

Sampath invoked the German historian Arthur Rosenberg's Fascism as a Mass Movement (1934) whose first-ever English translation had been published as Fascism: Essays on Europe and India in January 2016 in India by the Three Essays Collective. The book traces the emergence of Fascism in Europe in a short introduction, and then extends the framework to India in four essays. (We know that Kanhaiya's speech had made the connection of Modi with Fascism explicit, and that he recently responded to Prakash Karat's attempt to reconfigure Modi as 'authoritarian' rather than fascist with an invitation to the academic to head to New York if he was unwilling to fight.) Sampath found the pattern in the events unfolding first in Hyderabad and then in Delhi 'too striking to miss'. In Hyderabad, in his words, 'a pliant vice-chancellor and a pliable police acted against the students targeted by the ABVP, and the story hit the national headlines with the suicide of Rohith Vemula, a vocal critic of the ABVP and its violent majoritarianism'. He continued:

In JNU [too], the crisis was sparked by a group of students organising a protest meeting in support of Afzal Guru, whose execution has been questioned by several legal luminaries. The ABVP spearheaded the persecution of the students involved 
by branding them as "anti-national". Its case was taken up by a BJP MP, Maheish Girri, whose complaint led to an FIR being lodged. The outcome: a pliant vicechancellor and a pliable police acted against the students targeted by the ABVP, and the story hit the national headlines with the arrest of JNU students' union president Kanhaiya Kumar, a vocal critic of the ABVP and its violent majoritarianism. (Sampath 2016)

What he doesn't point out, however, is that this system of punitive action against offending individuals by such storm troopers has been operational in India for a very long time. Taking upon itself time and again the right to label and then persecute anybody who displeases it, violence has been used by vigilante groups for some time now. Governments have been reluctant to act against offended parties, thus a Congress government in power doesn't necessarily have a better track record in such cases. The charge of being 'anti-national' is proven by simply being stated by the offended party, who are always Indians acting in the name of either Hinduism or the nation, which seem to be synonymous to them, as Wendy Doniger found out in relation to her book, The Hindus: An Alternative History. In the context of the University, 'the battle is already lost if one seeks to answer the charge by trying to prove that one is not an anti-national' The Hindu went on to say, concluding: 'The correct response, as Mr. Kumar showed in a brilliant speech that went viral on social media, is to go on the offensive, and ask what qualifies goonda nationalists to issue certificates of nationalism, and to question the motives of a government that allows them to do so.'

\section{WHO SINGS THE NATION-STATE?}

In a 2007 conversation between Judith Butler and Gayatri Spivak brought out by the Calcutta-based Seagull publishers titled who sings the nation-state? Butler ruminates, at the start of the discussion, on what it means to be 'at once contained and dispossessed by the state'. Reflecting primarily upon refugees/ political prisoners/ asylum seekers, she outlines a conundrum that seems basically also to underlie the conflicted position occupied by many of the protesting students on the Left or of Dalit dispensation at Hyderabad and JNU, in that these are citizens of the nation who have been bound - just as the hyphen binds nation to state- by the state as well as unbound. For the state binds, she says, in the name of the nation, 'conjuring a certain version of the nation forcibly, if not powerfully', but if 'the state is what "binds," it is also clearly what can and does unbind'. This unbinding is figured in terms of expulsion and banishment for the dispossessed that are expelled

... precisely through an exercise of power that depends upon barriers and prisons and, so, in the mode of a certain containment. We are not outside of politics when we are dispossessed in such ways. Rather, we are deposited in a dense situation of military power in which juridical functions become the prerogative of the military. This is not bare life, but a particular formation of power and coercion that 
is designed to produce and maintain the condition, the state, of the dispossessed. (Butler and Spivak 4-5)

Butler turns to Arendt rather than Agamben - a move that has been questioned, but that we will not discuss here- for 'thinking through statelessness in the present time'. The strong case Arendt makes for performative speech, 'speech that founds or "enstates" a new possibility for social and political life' in an essay in The Origins of Totalitarianism is prescient in referring to statelessness: the nation becomes homogenous to comply with the force of the state.

In the case of the current student unrest in India, juridical functions became the prerogative of the government rather than the military, but the exercise of power that produces statelessness was achieved by the same means — barriers and prisons. The state acted so as to produce the students as the stateless, and containment was attempted through 'a particular formation of power and coercion'. The immense irony of the scene in Delhi in March 2016 compared to the situation Butler outlines is that this is the state acting against its own rights-bearing citizens in the name of the nation. Punning on 'state', Butler reflects on 'the state we're in (which could, after all, be a state of mind')' when we ask about the hyphen linking nation to state. The refugee 'passes through a border and... arrives in another state' - what characterises the state arrived at? 'But this is where we do not know whether the state at which one arrives is defined by its juridical and military power and its stipulated modes of national belonging under the rubric of the citizen, or by a certain set of dispositions that characterize the mode of non-belonging as such.' (6)

In the University contexts of the protesting students, it would be the latter. Both Rohith and Kanhaiya and their groups seem to fit this other mode of non-belonging that is defined by 'a certain set of dispositions that characterize the mode of non-belonging as such' vis-a-vis the juridical and military power of the state and its stipulated modes of national belonging. Butler mentions Guantanamo and Gaza in this context, but in addition, she is also concerned with internallydispossessed populations, those who are "stateless within the state, as seems clear for those who are incarcerated, enslaved, or residing and laboring illegally" (16). In India this year, students like Kanhaiya Kumar, Umar Khalid, Anirban Bhattacharya and others saw themselves terrorized by an exercise of power that depended heavily on state intervention, the police, barriers, and prisons, modes of 'a certain containment' that worked against its own citizens, turning them into a version of dispossessed populations. This was not self-appointed military power, but a democratically elected government exercising power against young students of the country through methods usually deployed against the dispossessed other - the Palestinian, the terrorist, the refugee.

What are the acts of sovereignty by which constitutional protections are withdrawn and suspended? Butler asks the question in relation to refugees, to the stateless, but how may we re-ask it in the context of student movements in India today? Student populations are always under the control of state power, and that power has been used, in these two instances, to displace and dispossess certain student groups branded 'anti-national' by a regime in power. Expulsions, incarcerations, and 
fines have been used to reduce and strip the agitating students to a state of powerlessness that has been 'actively produced, maintained, reiterated, and monitored by a complex and forcible domain of power' (10-11). The students are then produced as the stateless, even as they try and wrest the constitution from the machinations of state power toward a symbolization of guaranteed rights, their rights. While the state tries to contain and exclude those students to be produced 'as a stateless person [is] contained and restricted by the juridical and military operations of state power', the students, on the other hand, avail of legal representation and claim their rights through sheer rhetoric, the conspicuous waving of the national flag, and affirmations of their belief in the constitution. These important gestures make a paradoxical claim on belonging alongside the mode of non-belonging that needs to be understood as acts of declaration, performative acts, important rhetorical movements, of a call to freedom. Two paradoxes seem evident here: first, the state produces its own children as the stateless; and second, the protestors who are branded anti-national then claim the nation through symbolic appropriation and legal representation.

The first paradox of the state producing its own children as the stateless has parallels in other spheres of politics worldwide. Etienne Balibar, in an essay titled 'Europe at the Limits', speaks of how the 'old conflicts, the old resistances, the old commitments have become obsolete'. He says:

Rather, I submit that they have become supplemented by others which make for a much more complex and politically uncertain pattern, adding at the same time new resources of intelligibility and civic innovation (what I would like to call 'insurrection', in the broad sense) and formidable obstacles to any simple programme of emancipation, in which the positions of oppressors and oppressed could be assigned to antithetic separated groups formed by history. (Balibar 171)

'Internal aliens' is the term Balibar uses here to refer to the 'excluded categories' within post-national societies such as exist in Europe today, wherein he means the 'increasingly divided and heterogeneous non-European other' found within those settled in Europe from former colonies. But in a unique twist, the Indian government seems to have become the prototype of 'the sort of demagogic governments who advocate the return to an ideal nation and its "dominant culture" as a recourse against the destabilizing effects of protests by its own student populations who speak in a voice different from their own. As in Europe, so the Indian government's discriminations against those opposed to them ideologically seem to 'bring to the fore symbolic dimensions which have a far longer history and another source of mutual exclusion (such as religious antagonism)' (170).

Song enters Butler and Spivak's discourse in who sings the nation state through the question: 'who sings the national anthem' in the context of an incident that Butler recounts:

In the spring of 2006, street demonstrations on the part of illegal residents broke out in various California cities, but very dramatically in the Los Angeles area. The US national anthem was sung in Spanish as was the Mexican anthem. The emergence of "nuestro himno" introduced the interesting problem of the plurality 
of the nation, of the "we" and the "our": to whom does this anthem belong? If we were to ask the question: what makes for a non-nationalist or counter-nationalist mode of belonging? ( 27)

(Gayatri, unusually, barely gets a chance to speak in this text, mostly interjecting with - I quote-: 'carry on' or 'but you have more, no?' or 'go on for as long as you like' when invited by Butler to say anything.) The question Butler asks is relevant for us if we were to relate it to Kanhaiya's speech and azadi song and the politics of protest among Dalit and Left students in the country today: 'what makes for a non-nationalist or counter-nationalist mode of belonging?' In JNU, it was not the national anthem that was being sung in a different language, of course, but a song that called for freedom in which we witness the same two things Butler finds in the Spanish anthem, 'the assertion of equality' and 'the exercise of freedom'. She says:

I want to suggest to you that neither Agamben nor Arendt can quite theorize this particular act of singing, and that we have yet to develop the language we need to do so. It would also involve rethinking certain ideas of sensate democracy, of aesthetic articulation within the political sphere, and the relationship between song and what is called the "public."...

At this point, the song can be understood not only as the expression of freedom or the longing for enfranchisement - though it is, clearly, both those things - but also as restaging the street, enacting freedom of assembly precisely when and where it is explicitly prohibited by law. This is a certain performative politics, to be sure, in which to make the claim... is made nonetheless and precisely in defiance of the law by which recognition is demanded. (62)

\section{THE UTOPIA OF PURE POLITICS}

Following the events on the JNU campus, the TSR Subramanian panel's report on the new education policy took up several pages to recommend restrictions on campus activism. Reading these recommendations in the light of recent events, Kavita Krishnan, politburo member of the Communist Party of India (MarxistLeninist) and a former joint secretary of the JNU Students' Union said:

The government of the day had chosen to brand Ambedkar Student Association - of which Rohith Vemula was a part- and Ambedkar-Periyar Study Circle as "casteist", while the Akhil Bharatiya Vidyarthi Parishad, which violently imposes casteism, patriarchy and Hindu fundamentalism on students, is deemed "nationalist". The Bharatiya Janata Party government has made no secret of its hostility to free speech and dissent, even as it has nurtured hate speech. The Subramanian panel report, then, sits well with its agenda of delegitimising dissent on campuses by branding such student movements as a "distraction" while a fictitious "silent majority" is projected, with no basis in fact, as victims of the movements. (Krishnan 2016) 
University activism has been on the increase in India in the last few years. Krishnan lists some of the recent developments in campuses across India. In Delhi University, students made their voice heard in referendums against the politically imposed Four Year Undergraduate Programme and Choice Based Credit System that were destroying the quality of education. In Jawaharlal Nehru University, agitations over the years have secured and safeguarded socially just admission policies, measures against casteism and sexual harassment as well as hostel and library facilities. They have also helped implement labour laws for campus workers. In the University of Hyderabad, students are protesting against deeply entrenched casteism. Further, the Hok Kolorob protests of 2014 in Jadavpur University and the recent movement against the crackdown in JNU have seen thousands of students from other colleges and universities joining in the demonstrations spontaneously. On what basis then, she asks, has the Subramanian panel said that a "majority of students" are against such agitations for equitable education and for democratic rights? She ends on a Utopian note:

Campus activism is not a "distraction" from "studies", as the Subramanian panel report claims. The world over, it is a sign of hope - of a younger generation committed to fighting for a better world. And the world over, rulers are afraid of publicspirited, thoughtful young people who refuse to do what they are told by those in power. They are afraid of teachers and students who refuse to see education as a tool wielded by those in power. Education policy should be shaped by youthful hope, not by the rulers' fear. (Krishnan 2016)

Without in any sense retreating from the real gains that protests such as those listed by Krishnan may result in, or dismissing in any way the actual advancement that can only result from activism such as this, I am interested here in focusing on the Utopian notion of a better world projected by this well-known left activist in the context of Indian student protests in recent times. Krishnan's Utopian vision that sees a beacon of hope in student protests is similar, in a sense, to the classic definition of Utopia as the dream of a perfect world, a world free of conflict, hunger and unhappiness.

The Azaadi chant was assumed by some to be a gift from Kashmir separatists, but its genealogical origins are as a feminist number against patriarchy. The Hindustan Times reported on $5^{\text {th }}$ March that it was evolved and popularised by well-known feminist Kamla Bhasin in the women's movement all over south Asia:

The "Azaadi" chant by Jawaharlal Nehru University (JNU) student leader Kanhaiya Kumar, which has become the heartbeat of a section of the youth today, is not a gift from Kashmir separatists, as is being assumed.

Interestingly, the chant originated as a feminist number against patriarchy. It was evolved and popularised by well-known feminist Kamla Bhasin in the women's movement all over south Asia.

An early memory of dancing and chanting to the catchy beat of the "Azaadi" number dates back to 1991, at the Women's Studies Conference in Kolkata's Jadavpur University. A vibrant and charismatic Bhasin, in her early forties, chanted it with 
a little drum in hand and women surrounded her, throwing their fists in the air. My five-year-old daughter, who had accompanied me there once, caught on the song and chanted it throughout her childhood.

The original words coined by Bhasin were "Meri behane maange Azaadi, meri bachhi maange Azaadi, naari ka naara Azaadi... (My sisters want freedom, my daughter wants freedom, every woman's slogan is freedom)". ${ }^{2}$ (Dutt 2016)

Recalling the roots of the poem, Bhasin said she had learnt it from Pakistani feminists and later improvised the words. The chant became so popular that it reached the Left and other groups wanting freedom from injustice of any kind. Feminist activist Urvashi Butalia, founder-publisher of Zubaan, recalls, "It was one of the most popular poems of the feminist movement. Later, it became an inspiration for other groups too" (Dutt 2016).

Listening to the speech and song in real time, Jyoti Malhotra, writing in the Daily $\mathrm{O}$ on $4^{\text {th }}$ March, just a day later, asked, 'How many times can you demand "azadi" in the space of 51 or so minutes?' and answered:

If you're Kanhaiya Kumar and you have recently returned to Jawaharlal Nehru University after spending 20 days in Tihar jail, you can transform that single, allegedly seditious word, first into an invocation, then a chorus, soon a litany, until, finally, it is exhaled from your mouth on a wing, perhaps even a prayer. (Malhotra 2016)

She concluded: 'Last night, JNU must have gone to sleep much later than the rest of the India... Actually, India was watching, live, Kanhaiya Kumar's speech on TV, knowing that something has shifted. We are changed, hearing Kanhaiya Kumar, back home in JNU. For a few hours more, we can dare to believe that we have dared to participate in that change.' It is this language and this feeling - not uncommon either in the reportage (the adjective most frequently used of it in the following days was 'electrifying'; other descriptions included 'fiery', 'impassioned', and 'blistering') or in the responses of the viewing public at that time - a feeling of belief, of hope, of something having shifted, a feeling almost unbelievable in today's society and everyday experience. It doesn't need saying that the feeling is obviously not one common to everybody; I'm sure the ABVP activists and the ruling dispensation had other feelings on the matter.

The phrase that came to repeatedly mind to describe this moment of the speech and the song was 'pure politics': this was politics untainted by personal motive, politics in its purest and most unadulterated form, politics free of self interest or electioneering, politics that was the articulation of an ideal, that embodied a utopia of longing. Although the words lal salaam resonated in the air, and a repetition of

2 Nirupama Dutt “'Hum kya chahte? Azaadi!” Story of slogan raised by JNU's Kanhaiya' The Hindustan Times, March 5 ${ }^{\text {th }}$, 2016. See: https://www.hindustantimes.com/punjab/kanhaiya-kumars-azadi-chant-not-a-gift-from-kashmir-separatists-but-from-feminists/story-K7GQNzhzE1Z8UFBDGVYh6J.html. 
inquilab was a part of the refrain, the moment strangely transcended party lines; as Indian Express correspondent Tunku Varadarajan said, for him it was 'pure protest poetry', and he vows he is no Marxist. This was not politics in its everyday form, the moment somehow seemed to transcend the ordinary or the routine, it was, in a sense, above politics. Which then leads us to the realisation that the phrase 'pure politics' is normally used to denigrate, to imply that something is a result of pure politics is to indicate corruption in the system. Sunil Khilnani discusses the concept of politics in the Indian context in his Idea of India when he articulates how politics was conceived of in the time of Nehru and Gandhi as 'a necessarily undeterminable field of human agency, a space of constantly competitive, strategic and practical action', a field that by the end of Indira Gandhi's life had fallen into 'corruption and degeneration. Politics and the state, once seen as the prophylactic that would invigorate the country, were now seen as the disease (3).

The sense in which the term 'pure politcs' is being used here, then, is the inverse of the common understanding of it as 'a space of constantly competitive, strategic and practical action', indicating exactly the opposite, of being in some way above politics. Searching for a similar moment to this in the history of independent India, the only instance that came to mind was Nehru's famous 'Tryst with destiny' speech. That speech too, made at the founding moment of India's freedom, was above politics in a similar way. It transcended party lines, it transcended electioneering, it was untainted by personal investment -in all these ways it was similar, although the comparison is almost embarrassing to make. What both speeches also share is that both were broadcast live- one on the radio, and later on film newsreels and documentaries, repeated endlessly and familiar to all; and the other broadcast live on tv and available on YouTube to be accessed at any time as it has been already a staggering number of times.

I want to conclude by bringing Spivak back into the conversation she seemed to have been left out of earlier. In a lecture titled Nationalism and the Imagination published three years after the conversation with Butler in 2007, Spivak, for no reason that she outlines self-consciously, chooses to begin by invoking her memories of 'the extraordinary songs of the IPTA [= Indian People's Theatre Association], the songs of the patriotic D.L. Roy drama Mebar Patan sung 'every Independence day', and the street rhyme about the Japanese popular in Calcutta in the 1940s. The ingredients of nationalism, she realises from these instances, are 'to be found in the assumptions of what I later learned to call reproductive heteronormativity' 'as a source of legitimacy' (Spivak12-13). Song returns in her discussion in the songs of the tribal Sabar men and women, inventive 'oral-formulaic presentations' of 'thinking without nation'. She returns here to Arendt's perceptiveness with regard to what she christens the 'nation thing' in suggesting that 'the putting together of nationalism with the abstract structure of the state was an experiment or a happening that has a limited history and a limited future. We are living, as Jurgen Habermas says, in post-national situations.' (14)

Further, what the nation thing conjures is 'a rock-bottom comfort in one's language and one's home [which is] not a positive affect'. 'In whatever nationalist colours they are dressed, whether chronological or logical, the impulse to nation- 
alism is "we must control the workings of our own public sphere" (p. 18) Ending 'by speaking of the reinvention of the state' rather than the easy 'nation-state' that rolls off our tongues, she imagines a 'so-called Global South' 'free of the baggage of nationalist identitarianism, and inclining towards a critical regionalism, beyond the national boundaries'. 'As for me,' she concludes, 'I am altogether utopian. I look towards a re-imagined world that is a cluster in the Global South, a cluster of regions... Imagine this, please, for a new world around the corner. Thank you.' $(49,58)$ Which is precisely what the azadi song sung by Kanhaiya and thousands of others seems to say to us: 'Imagine this, please, for a new world around the corner.'

Reviews sent to author: 3 November 2017

Revised paper accepted for publication: 12 February 2018 


\section{REFERENCES}

Balibar, Etienne. 'Europe at the Limits,' Interventions, 18: 2 (2016).

Butler, Judith and Gayatri Spivak. Who Sings the Nation-State? Seagull, 2007.

DutT, Nirupama. "Hum kya chahte? Azaadi!” Story of Slogan Raised by JNU's Kanhaiya'. The Hindustan Times, March 5 ${ }^{\text {th }}$, 2016. See: https://www.hindustantimes.com/punjab/ kanhaiya-kumar-s-azadi-chant-not-a-gift-from-kashmir-separatists-but-from-feminists/ story-K7GQNzhzE1Z8UFBDGVYh6J.html. Accessed 9 March 2018.

High Court of Delhi. "Kanhaiya Kumar bail order." 2 March 2016. https:/es.scribd.com/ doc/301716807/Full-text-Kanhaiya-Kumar-bail-order. Accessed 10 March 2018.

Khilnani, Sunil. The Idea of India. Hamish Hamilton, 1997.

Krishnan, Kavita. 'By Trying to Silence Campus Activism, Education Policy Report Is Ignoring the Voices of India's Students,' Scroll.in 25 June 2016. https://scroll.in/article/810505/by-tryingto-silence-activism-the-education-policy-report-is-turning-a-deaf-ear-to-students-voices. Accessed 8 September 2016.

Malmotra, Yioti. “The Night Kanhaiya Kumar Reclaimed JNU and Azadi.” 4 March 2016. https://www.dailyo.in/politics/kanhaiya-kumar-released-jnu-row-delhi-hc-sabarmatidhaba-azaadi-rohith-vemula-narendra-modi-anti-national/story/1/9356.html. Acccessed 18 February 2018.

Sampath, G. "Who Is an Anti-national." The Hindu. 17 February 2016. http://www.thehindu.com/ opinion/op-ed/Who-is-an-anti-national/article14082785.ece. Accessed 18 February 2018

SPIVAK, Gayatri. Nationalism and the Imagination Seagull, 2010.

Varadarajan, Tunku. “The Beauty of Sedition,” Indian Express, 6 March 2016. http://indianexpress. com/article/opinion/columns/reverse-swing-the-beauty-of-sedition-jnu-jnu-row-kanhaiyakumar/. Accessed 18 February 2018.

Vermula, Rohith.”My Birth Is My Fatal Accident." Outlook India, 18 January 2016. https://www. outlookindia.com/website/story/my-birth-is-my-fatal-accident/296429. Accessed 18 Februay 2018.

VIJ, Shivam. "Kanhaiya's Bail Judgement Begins With 'Mere Desh Ki Dharti'." Huffington Post, 2 March 2016. https://www.huffingtonpost.in/2016/03/02/story_n_9367810.html. Accessed 9 March 2018. 